\title{
TAXATION AFTER THE WAR
}

By Simon N. Patten,

Professor of Political Economy, Wharton School, University of Pennsylvania.

Few realize the changes in taxation that will be wrought by the war. Up to the present time no one of the warring nations has increased its taxation in such a manner as would permit their new obligations to be met. Each has piled up a huge debt, and all assume, or perhaps it is better to say, hope to be victorious, and that an indemnity will be obtained from their foes freeing them from taxation.

For the student it is not so much the question of who shall pay as it is the amount to be paid. The importance of this is increased by the fact that it is unlikely a decisive victory will be won by either party, or at least such a one as would allow them to demand huge indemnities from their opponents. Let us assume that the war continues for three years, and on that basis measure the burden that will be imposed upon the various European nations. It is generally assumed that at the end of eighteen months the total burden of the war had been $\$ 40,000,000,000$. This, however, does not include the guarantees the various nations have made, nor the losses in property in Belgium, Poland, Servia, and other devastated regions. If all these are included at the end of the third year the cost of the war will be over a hundred billion dollars, which may be roughly divided as follows: England, 40 billion, France, 15 billion, Germany, 25 billion, and 5 billion to restore the devastated regions. This would leave 15 billion to be borne by Austria, Italy, or Russia. An important journalist recently said that such an amount could not be paid, but that the debt would be transformed into rentes of the character the French now use. Every creditor then would have a right to his interest, but have no right to the collection of the principal. Should this be done, the hundred billion dollars of indebtedness would at the present rate of interest demand an annual levy of 5 billion dollars a year. If the present amount of taxation that the people in the various countries in Europe pay is added to this, it will demand a quarter of the income of the people. What method of taxation could raise this vast amount? 
Up to the present time only one theory of taxation has been proposed that has a rational basis. This theory is called the "single tax," and its most noted advocate was Henry George. The supposition on which it is based is that the income from land is a differential due to differences in the fertility of the soil; the revenue from land is therefore a surplus revenue, or as it is often called, an unearned income. The single tax proposes to appropriate this surplus income and thus meet the burden of taxation. Under the old conditions of taxation this might have been done, but when an attempt is made to raise 5 billion dollars a year from this one source the tax would prove insufficient. We must therefore revise the theory of taxation so as to obtain increasing revenue. The doctrine of surplus income from land is correct, and in this respect the theories of Henry George are unassailable; but George assumed as a part of his theory that men are born equal, and that income other than from land is distributed according to the ability and earning power of men. This, however, is not a fact. The equality of men is a political dogma and not an economic tendency. The differences in the productive power of men due to their heredity or social position give to certain individuals the same kind of an advantage over others that the owner of a corner lot in the center of a city has over one in the suburbs. If the income from a corner lot is a surplus and can therefore be described as unearned, the income of a man of better heredity, education or opportunity must also be regarded as a surplus income and therefore unearned. For the cause of the difference in men we should turn from economics to biology in which the laws of inheritance rest-the so-called Mendel law. The assumption of this law is that in the average family of four children one will be superior, two will be mediocre, and the fourth sub-normal. Then in the average family we would have one superman, two commonplace individuals, and one defective. The situation is worse than this because a large part of the population are for other reasons defective, or have come from foreign countries, and thus cannot take advantage of the opportunities that America affords. It is a modest statement to say that a third of our population belongs to this inferior class, and, if so, the proportion of the various classes would be one superman, two mediocre, and three sub-normal. The superman has an income, say of $\$ 3,000$ a year; the two mediocre people an income of $\$ 900$ each; while 
the three sub-normal people have $\$ 400$ each. This would mean that in an average community one person in six would have half of the income that the whole six have.

These differences are probably an understatement since investigators assume a different rate of increase for the different classes. The superior classes do not have more than two children to a family. The mediocre may be assumed to have three children to a family, and the inferior groups at least four children to a family. With these different rates of increase taken into consideration we would have our ratios of income changed from $1: 2: 4$ to $1: 3: 8$, which would make the superior class only one twelfth of the community, with more than half its total income.

In addition to these differences in heredity we also have marked differences due to ancestral conditions, since a great part of private property is inherited by a relatively small class. Adding together the geographical, the industrial, the ancestral advantages, the net result would be that one-tenth of the people have at least one-half of the national income, and the other nine-tenths less than the other half. This is a moderate estimate; the difference is often put much greater. It is claimed that 2 per cent of the population have half of the national income. Even at best these conditions are bad enough and illustrate the need of new methods of taxing surplus income.

The urgency of tax reform is not so great in America as in Europe, and yet the conditions are the same. The limits to old forms of taxation have been reached, and a large increase of revenue is demanded by city, state and nation. On top of these is the demand for large expenditures for national defense which a new group of alarmists has raised. The figures I give are therefore based on American conditions of which the facts are at hand. To apply them to Europe after the war demands that each figure be doubled, while the resources from which the taxes are to come are not half as great per man.

The amount of property in the United States is estimated by government officials to be 200 billion dollars. If this be correct, about 80 billion of this is surplus value-that is, a value that has no corresponding material wealth on which it is based. It is merely capitalized income due to some controlled advantage. Forty billion would represent land values; another 40 billion, the fixed capi- 
tal; while a third 40 billion would represent circulating capital. These are rough estimates, but they probably come close to actual facts. The gross income of the nation is about 20 billion dollars. Ten billion of this comes from property which is a return at 5 per cent on 200 billion dollars; 5 billion would form the income of the superior class, while a second 5 billion would represent the real wage of the workers. The basis of this final assertion is that we have 100 million population. Of this, however, 10 million are either unemployed or partly employed. There are 8 million dependents; 2 million belong to the leisure class. This would leave 16 million working families and give them a minimum income of 300 dollars per family.

On this basis our annual income of 20 billion dollars would be divided as follows: Two billion dollars would go as ground rent, 3 billion to those who inherit wealth, 5 billion to the marginal laborers, while 10 billion, or half of the total national income, would go as a reward for opportunity and talent. It should be noticed that this method of division does not separate workmen from employers or the leisure class, but separates the earned minimum of $\$ 300$ from the surplus income which opportunity, advantage or inheritance gives to superior persons. If, for example, a trade union keeps its rate of wages at $\$ 800$ a year, $\$ 300$ for each person is credited to the minimum standard, the total of which is 5 billion dollars, and the other $\$ 500$ per man is credited to surplus income. The advantage of a trade unionist is not so great as that of a great author or inventor, but it is of the same class and should be regarded as part of the same fund.

If these are the facts, the basis of taxation should not be a single tax on land, but a triple tax on income, inheritance and land. Income from any of these sources is unearned income, as this term is defined, and is therefore a legitimate object of taxation. The revenue derived from these sources stands in the ratio of $\$ 5$ from income to $\$ 3$ from land and $\$ 2$ from inheritance. If the tariff is retained the proportion would be $\$ 3$ each from income and tariff to $\$ 1$ each from land and inheritance.

My conclusion is that the single tax would fail if it were used as a basis of taxation after the war. Surplus income is, however, just as legitimate a basis of taxation. From it the necessary increase of taxation can be derived without trenching on the standards of 
the marginal workers. So large a sum, however, cannot be raised through schemes that would tax only the rich. The minimum would have to be as low as $\$ 2,000$ a year. Taxes on large incomes look attractive, but they do not yield large sums.

If the people of the United States desire to spend vast sums for national defense, or for any similar purpose, the real burden must be borne by families with incomes from $\$ 1,500$ to $\$ 5,000$ a year. And the tax must be largely in the form of an income tax. The tariff may be altered, but the sum it would yield cannot be greatly. increased. The comforts of the great middle class will have to be foregone to meet the increased national expenditure. Whether or no the average family will make this sacrifice will be the final test of the movement now brewing to prepare for war instead of genial prosperity. Until the tax gatherer reaps his harvest we know little of what the American people will do, and still less of how the already hard-pressed nations of Europe will react when they become conscious of the great burden the war has imposed. There is a fascination about spending that few can resist, especially when they are spending other people's money. It seems a sad fate if all the material advantage of the nineteenth century is to go into the hand of the bond-owner and his heirs. 